\title{
BIOLOGY AND MANAGEMENT OF ALLOKERMES KINGII (HEMIPTERA: KERMESIDAE) ON OAK TREES (QUERCUS SPP.)
}

\author{
By Jay Cee L. Turner ${ }^{1}$ and Eileen A. Buss ${ }^{2}$
}

\begin{abstract}
The northern red-oak kermes scale, Allokermes kingii (Cockerell), is a native, gall-like scale insect found on oak trees (Quercus spp.) in the United States. Its feeding causes branch dieback, flagging, reduced growth rates, and occasionally tree death. Allokermes kingii has one generation a year throughout most of the United States, but we found two generations a year in Florida. It also infests Q. geminata Small and Q. virginiana Miller, which represent new host records. The insecticides tested (acephate, bifenthrin, imidacloprid, horticultural oil, and combined acephate and oil) appeared to suppress the nymphal population, but none caused $>42 \%$ mortality. Very few natural enemies occurred on the study trees, and were thus considered ineffective at reducing the scale population at this site.

Key Words. Allokermes kingii; insecticide trial; Kermesidae; northern red-oak kermes; Quercus geminata; Quercus virginiana.
\end{abstract}

Kermes scales (Hemiptera: Kermesidae) are native, gall-like insects that primarily infest oak trees (Fagaceae: Quercus spp.) in the eastern and midwestern United States (Kosztarab 1996; Scalenet 2004). Their feeding often results in branch dieback or reduced tree growth rates (Raven 1983; Vranjic 1997), and their honeydew secretions result in sooty mold growth on branches. Severely infested trees may die if populations are not suppressed (pers. obs.).

The most economically damaging kermes scales are Allokermes cueroensis (Cockerell), A. galliformis (Riley), and A. kingii (Cockerell) (Kosztarab 1996). Of these species, however, only the life cycle of A. kingii has been studied (Hamon et al. 1976), and little is known about the biology of other scales in the family Kermesidae (Kosztarab 1996). Large (4 to $5 \mathrm{~mm}$ [0.16 to $0.2 \mathrm{in}$.]), round, mottled-brown females feed along branches, in tree wounds, at the base of buds, and at the base of leaf petioles (Hamon et al. 1976). Tiny (1 mm [0.04 in.] long), white, oval males occur in bark crevices along tree stems. In Virginia, A. kingii has one generation each year (univoltine).

Oaks are commonly planted street trees in the United States, and live oak (Q. virginiana Miller) is a particularly popular species in Florida (Harms 1990). Infestations of A. kingii appeared to be developing faster on live oaks in Florida nurseries and urban landscapes than expected for a univoltine species, and management based on the life cycle determined in Virginia was ineffective. Thus, we examined the life cycle and insecticidal control of A. kingii on street trees in central Florida.

\section{MATERIALS AND METHODS Study Site}

Eight oak trees (two sand live oaks [Q. geminata Small] and six live oaks [Q. virginiana Miller]) with natural infestations of A. kingii in Clearwater, Florida (Pinellas County), U.S., were examined from May 2002 to August 2003. The trees were located in a parking lot about $300 \mathrm{~m}$ (328 yd) from the Gulf Coast. On 10 May 2002 and 29 August 2003, tree height was measured using a clinometer, and diameter at breast height (dbh, $1.4 \mathrm{~m}$ [55.1 in.]) and crown diameter were measured with a centimeter cloth measuring tape.

\section{Life Cycle}

To determine the life cycle of A. kingii, five branches (20 to $26 \mathrm{~cm}$ [8 to $10 \mathrm{in}$.] long), approximately 1.8 to $3.7 \mathrm{~m}$ (5.9 to $12.2 \mathrm{ft}$ ) off the ground, were cut from each tree every 2 to 3 weeks from 6 June 2002 to 29 August 2003. Branches were transported to the laboratory in a cooler, frozen, and later examined with a dissecting binocular microscope (10x to $20 x$ ). The number of live first and second instars and live female adults on each branch was counted and totaled by life stage for each tree. The total number of live A. kingii (all life stages combined) per main branch and lateral branches, the total length of each main branch, and the total number and length of lateral branches per main branch were recorded. Male A. kingii were primarily located on tree trunks, rather than branches, and were thus not examined in this study.

\section{Insecticide Test}

Insecticide applications were targeted against the first and early second instars of the first generation A. kingii. Six treatments were assigned to trees using a randomized complete block design, with five replicates (trees). Thirty oak trees naturally infested with A. kingii in Clearwater, Florida, were selected (height: $5.5 \pm 1.0 \mathrm{~m}[18.2 \pm 3.3 \mathrm{ft}]$; dbh: $22.8 \pm 3.3 \mathrm{~cm}[9.0 \pm 1.3 \mathrm{in}]$.$) . Trees were separated by$ 
4.3 to $5.5 \mathrm{~m}$ ( 14.2 to $18.2 \mathrm{ft}$ ), and branches were not interconnected. Treatments included label rates (listed in Table 1) of acephate (Orthene TT\&O $97^{\circledR}$, Valent USA Corp., Walnut Creek, CA), bifenthrin (Talstar Flowable ${ }^{\circledR}$, FMC, Philadelphia, PA), imidacloprid (Merit 75 WP ${ }^{\circledR}$, Bayer Environmental Science, Montvale, NJ), horticultural oil (Sunspray Ultra-Fine ${ }^{\circledR}$, Philadelphia, PA), horticultural oil plus acephate, and an untreated control. Adjuvant was not mixed with the insecticides. An ISA Certified Arborist applied the insecticides on 1 and 2 May 2003. Acephate, bifenthrin, horticultural oil, and horticultural oil + acephate were applied as foliar sprays using a hydraulic sprayer (pressure: $25 \mathrm{~mL} / \mathrm{m}^{2}$ [1 oz/ft $\left.{ }^{2}\right]$ ) with a $756 \mathrm{~L}$ (200 gal) agitating tank and a single, handheld sprayer. Trees were sprayed until runoff. For a soil drench, imidacloprid was sprayed with an 18.9 L (5 gal) Solo backpack sprayer within a tree's drip line, until the soil was evenly saturated. Equipment was triple-rinsed between treatments. Air temperature, relative humidity, wind speed, and cloud conditions were noted at application.

Treatment efficacy was evaluated by collecting four branches from each tree and counting the total number of live and dead first and second instar A. kingii. One branch (20 to $26 \mathrm{~cm}$ [8 to $10 \mathrm{in}$.] long) was randomly cut from each of the four cardinal points of each tree, approximately 1.8 to $3.7 \mathrm{~m}$ (5.9 to $12.2 \mathrm{ft}$ ) up from the ground on 24 April (pretreatment), 9 May (1 week after treatment, WAT), 22 May (3 WAT), 5 June (5 WAT), and 19 June (7 WAT) 2003. The branches were frozen, and scales were later examined with a dissecting binocular microscope. First and early second instars that survived the treatments were salmoncolored. However, insecticide-killed nymphs were slightly brown and shriveled. A waxy secretion normally coats the derm of healthy second instars, but those affected by insecticides had black spots on the wax layer.

\section{Statistical Analysis}

The mean number of healthy first and second instar A. kingii per four-branch sample was calculated using a one-way analysis of variance (ANOVA) $(P<0.05)$, and treatments were compared to the control using a Dunnett's test on each date (JMP®, SAS Institute 2001). The proportion of scale mortality was calculated by dividing the total number of dead nymphs by the total number of live and dead nymphs for each branch on each date. Proportions were arc-sine square roottransformed, analyzed with an ANOVA, and, if statistically significant, treatments were compared to the control using a Dunnett's test on each date (JMP $^{\circledR}$, SAS Institute 2001).

\section{RESULTS \\ Study Site}

This study was conducted on Q. geminata and Q. virginiana, which represent new host records for A. kingii. Tree height on 10 May 2002 was $5.9 \pm 0.7 \mathrm{~m}(19.5 \pm 2.3 \mathrm{ft})$, dbh was $51.7 \pm$ $14.3 \mathrm{~cm}(20.4 \pm 5.6 \mathrm{in}$.$) , and the crown diameter was 9.4 \pm$ $1.3 \mathrm{~m}(31.0 \pm 4.3 \mathrm{ft})$. Tree height on 29 August 2003 was 6.4 $\pm 1.0 \mathrm{~m}(21.1 \pm 3.3 \mathrm{ft})$, dbh was $52.4 \pm 14.8 \mathrm{~cm}(20.6 \pm 5.8$ in.), and crown diameter was $10.3 \pm 2.2 \mathrm{~m}(34.0 \pm 7.3 \mathrm{ft})$. From 6 June 2002 to 29 August 2003, we found 728.6 \pm 399.1 (range, 166 to 1,755$)$ A. kingii, all life stages combined, on 1,120 main branches $(22.9 \pm 2.3 \mathrm{~cm}[9.0 \pm 0.9 \mathrm{in}]$.$) and$ $781.6 \pm 309.2$ A. kingii (range, 371 to 1,586) on lateral shoots $(4.2 \pm 1.0 \mathrm{~cm}[1.7 \pm 0.4 \mathrm{in}]$.$) . The scale's life cycle did not$ appear to vary depending on the host tree species.

\section{Life Cycle}

Allokermes kingii has two generations each year in Clearwater, Florida (Figure 1). Salmon-colored crawlers emerged from late May to the first week of August in 2002. Females migrated to the larger branches, while males went onto the tree stem. Crawlers began to molt into second instars by mid-July. At this time, second instar females migrated to tree wounds or new growth, often near new leaf petioles, became sessile, and secreted a hard, waxy covering over themselves. Females molted into adults from late August to mid-December. A third instar was not observed in females in this study. Eggs were laid in female brood chambers and were present from early

September to mid-December.

Second-generation crawlers began emerging in midSeptember and some molted into second instars by midOctober. First and second instar nymphs overwintered on the trees. By late April to early May, female A. kingii molted into mature adults. Second-generation adult female A. kingii produced eggs until mid-June.

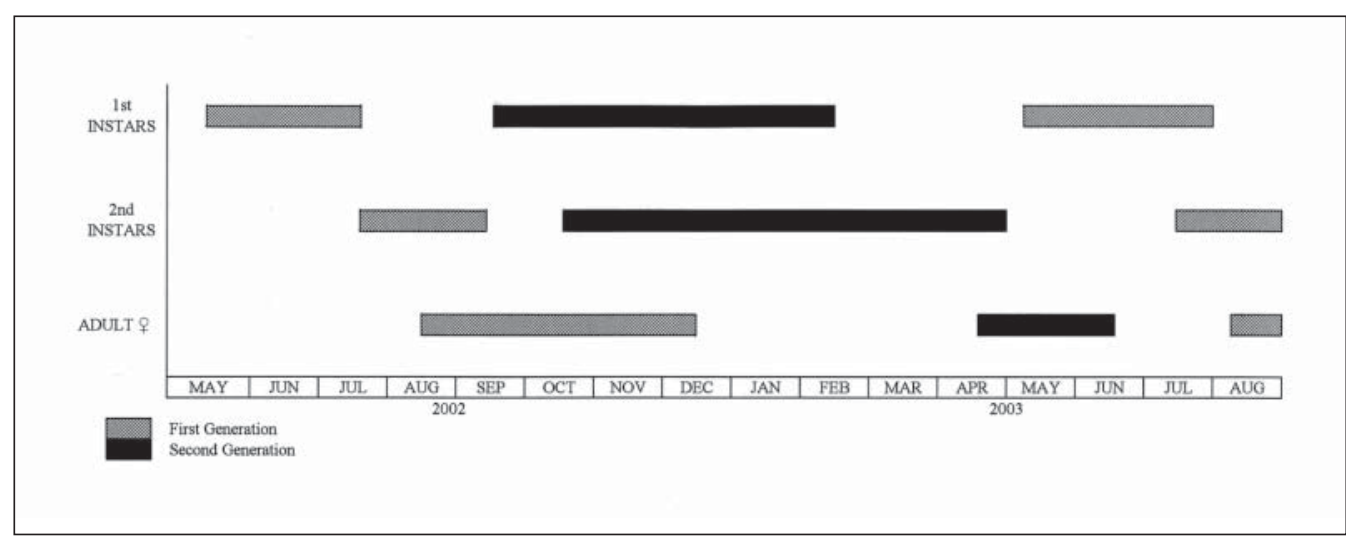

Figure 1. Seasonal life history of Allokermes kingii in Clearwater, Florida. 
Very few natural enemies were found attacking any of the A. kingii life stages. Generalist predators included ladybird beetles (Chilocorus cacti (L.), Harmonia axyridis (Pallas)), green lacewings (Chrysoperla sp.), and predatory caterpillars (Holcocera coccivorella (Chambers), Euclemensia bassettella (Clemens), Laetilia spp., and Pyroderces sp.). The only parasitoid recovered was Metaphycus sp. Ants (Pheidole dentata (Mayr)) tended A. kingii and were observed foraging on the scale honeydew.

\section{Insecticide Study}

From the beginning to the end of the applications on 1 and 2 May 2003, the air temperature ranged from $26^{\circ} \mathrm{C}$ to $34.2^{\circ} \mathrm{C}\left(78.8^{\circ} \mathrm{F}\right.$ to $\left.93.6^{\circ} \mathrm{F}\right)$, relative humidity ranged from $76 \%$ to $100 \%$, and wind speed ranged from 1.2 to $4.3 \mathrm{kph}$ (0.7 to $2.7 \mathrm{mph}$ ). Cloud conditions ranged from partly cloudy to overcast. About $1.3 \mathrm{~cm}$ (0.5 in.) of rain fell lightly for $15 \mathrm{~min}$ after the horticultural oil, acephate, and oil plus acephate applications on 1 May 2003. The imidacloprid soil drench was applied after the rain. The foliar bifenthrin spray was applied on 2 May because the wind speed increased to $>4 \mathrm{kph}(2.5 \mathrm{mph}$ ) on 1 May.

None of the insecticides tested provided consistent and satisfactory ( $>80 \%$ mortality) control of A. kingii nymphs (Table 1). Between 17\% and 38\% of the nymphs examined were dead within 1 week after treatment, but that number did not dramatically increase over time. Statistically more nymphs were dead from the acephate (33\%) and horticultural oil (27\%) treatments 3 WAT, compared to the control. However, the most mortality occurred 5 WAT, when nearly $42 \%$ of the nymphs were dead from the combined acephate and oil treatment.

Table 1. Mean $( \pm$ SEM) percentage of dead first and second instar Allokermes kingii per four-branch sample.

\begin{tabular}{|c|c|c|c|c|c|}
\hline Treatment & Rate & $\begin{array}{l}9 \text { May } \\
\text { (1 WAT) }\end{array}$ & $\begin{array}{l}22 \text { May } \\
\text { (3 WAT) }\end{array}$ & $\begin{array}{l}5 \text { June } \\
\text { (5 WAT) }\end{array}$ & $\begin{array}{l}19 \text { June } \\
\text { ( } 7 \text { WAT) }\end{array}$ \\
\hline Control & - & $5.7 \pm 3.8$ & 0 & 0 & $12.3 \pm 5.7$ \\
\hline Acephate & $\begin{array}{l}226.8 \mathrm{~g} / 378 \mathrm{~L} \\
(8 \mathrm{oz} / 100 \mathrm{gal})\end{array}$ & $31.7 \pm 4.1$ & $32.7 \pm 5.2^{*}$ & $11.0 \pm 3.2$ & $18.3 \pm 6.6$ \\
\hline Bifenthrin & $\begin{array}{l}2.3 \mathrm{~L} / 378 \mathrm{~L} \\
(0.63 \mathrm{gal} / 100 \mathrm{gal})\end{array}$ & $24.7 \pm 2.6$ & $16.0 \pm 6.7$ & $12.0 \pm 5.1$ & $9.7 \pm 2.7$ \\
\hline Horticultural oil & $\begin{array}{l}7.6 \mathrm{~L} / 378 \mathrm{~L} \\
(2.0 \mathrm{gal} / 100 \mathrm{gal})\end{array}$ & $37.7 \pm 11.1$ & $26.7 \pm 9.0^{*}$ & $15.8 \pm 3.0$ & $21.7 \pm 9.2$ \\
\hline Imidacloprid & $\begin{array}{l}5.7 \mathrm{~g} / 7.56 \mathrm{~L} \\
(0.2 \mathrm{oz} / 2.0 \mathrm{gal})\end{array}$ & $17.3 \pm 5.8$ & $11.3 \pm 5.7$ & $20.1 \pm 6.5$ & $24.2 \pm 3.6$ \\
\hline \multirow[t]{2}{*}{ Oil + acephate } & $\begin{array}{l}7.6 \mathrm{~L} \text { oil }+226.8 \mathrm{~g} \\
\text { acephate } / 378 \mathrm{~L} \\
(2.0 \mathrm{gal}+8 \mathrm{oz} / 100 \mathrm{gal})\end{array}$ & $23.6 \pm 10.7$ & $13.2 \pm 8.9$ & $41.7 \pm 19.3^{*}$ & $15.5 \pm 12.5$ \\
\hline & & $\begin{array}{l}F=2.33 \\
\mathrm{df}=5,24 \\
P=0.07\end{array}$ & $\begin{array}{l}F=3.89 \\
d f=5,24 \\
P=0.01\end{array}$ & $\begin{array}{l}F=2.62 \\
\mathrm{df}=5,24 \\
P=0.05\end{array}$ & $\begin{array}{l}F=0.70 \\
\mathrm{df}=5,24 \\
P=0.63\end{array}$ \\
\hline
\end{tabular}

* Means within a column followed by an asterisk are significantly different from the control (Dunnett's test) at $P<0.05$.
Nymphal survival decreased considerably in all of the treatments 1 WAT, compared to the pretreatment sample (Table 2). However, there were no differences among treatments, and the number of healthy nymphs on control trees also declined over time. Significantly fewer nymphs survived 3 WAT on trees treated with combined horticultural oil and acephate, compared to the control. The number of healthy nymphs increased on trees treated with acephate or bifenthrin 5 WAT and significantly so on bifenthrin 7 WAT, compared to the control. The population increase on 19 June 2003 in the bifenthrin treatment was largely from the crawler emergence from two female A. kingii. No other crawler emergence was noted from any other treatments or dates during the test.

\section{DISCUSSION}

Allokermes kingii has one generation a year throughout most of its North American range (Hamon et al. 1976), but it is now known to have two generations a year in Florida. In Virginia, females lay eggs (1,390 to 5,789 eggs per female) from July to August, eggs hatch from September to November, and the first instars are dormant until April. Then both female and male nymphs molt and migrate farther onto branches or the base of tree stems, respectively. Adults are present by mid-June in Virginia. The life cycle is more complex in Florida, with live adults present from April to December, first instars present from May to July and again from September to February, and second instars from July to September and October to April. The more rapid development of A. kingii in Florida is likely due to the warmer climate, longer growing season, and multiple-flushing growth habits of Q. geminata and Q. virginiana. Hosts include Q. borealis (L.), Q. coccinea (Muenchhausen), Q. ilicifolia (Wagenheimd), Q. imbricaria (Michaux), Q. laurifolia (Michaux), Q. phellos (L.), Q. rubra (L.), and Q. velutina (Lamarck) (Kosztarab 1996), and now also Q. geminata and Q. virginiana.

An integrated pest management program has not yet been established for A. kingii. Its natural enemy complex does not appear to adequately suppress populations, and environmental factors contributing to its 
Table 2. Mean ( \pm SEM) number of healthy first and second instar Allokermes kingii per four-branch sample.

\begin{tabular}{|c|c|c|c|c|c|c|}
\hline Treatment & $\begin{array}{l}\text { Rate } \\
\text { (product/water) }\end{array}$ & $\begin{array}{l}24 \text { April } \\
\text { (pretreatment) }\end{array}$ & $\begin{array}{l}9 \text { May } \\
\text { (1 WAT) }\end{array}$ & $\begin{array}{l}22 \text { May } \\
\text { (3 WAT) }\end{array}$ & $\begin{array}{l}5 \text { June } \\
\text { (5 WAT) }\end{array}$ & $\begin{array}{l}19 \text { June } \\
\text { (7 WAT) }\end{array}$ \\
\hline Control & - & $69.0 \pm 32.1$ & $66.6 \pm 24.0$ & $41.2 \pm 8.4$ & $43.2 \pm 13.3$ & $33.2 \pm 10.9$ \\
\hline Acephate & $\begin{array}{l}226.8 \mathrm{~g} / 378 \mathrm{~L} \\
(8 \mathrm{oz} / 100 \mathrm{gal})\end{array}$ & $100.0 \pm 54.8$ & $26.2 \pm 8.3$ & $13.4 \pm 2.4$ & $40.6 \pm 17.3$ & $41.2 \pm 21.4$ \\
\hline Bifenthrin & $\begin{array}{l}2.3 \mathrm{~L} / 378 \mathrm{~L} \\
(0.63 \mathrm{gal} / 100 \mathrm{gal})\end{array}$ & $85.0 \pm 24.0$ & $44.4 \pm 22.2$ & $16.8 \pm 7.7$ & $70.8 \pm 40.9$ & $308.2 \pm 118.7^{*}$ \\
\hline Horticultural oil & $\begin{array}{l}7.6 \mathrm{~L} / 378 \mathrm{~L} \\
(2.0 \mathrm{gal} / 100 \mathrm{gal})\end{array}$ & $94.0 \pm 25.9$ & $12.6 \pm 4.3$ & $13.0 \pm 4.9$ & $25.6 \pm 8.5$ & $23.6 \pm 6.1$ \\
\hline Imidacloprid & $\begin{array}{l}5.7 \mathrm{~g} / 7.56 \mathrm{~L} \\
(0.2 \mathrm{oz} / 2.0 \mathrm{gal})\end{array}$ & $117.8 \pm 49.6$ & $71.6 \pm 22.5$ & $56.0 \pm 14.2$ & $52.4 \pm 37.1$ & $57.6 \pm 27.3$ \\
\hline \multirow[t]{2}{*}{ Oil + acephate } & $\begin{array}{l}7.6 \mathrm{~L} \text { oil }+226.8 \mathrm{~g} \\
\text { acephate } / 378 \mathrm{~L} \\
(2.0 \mathrm{gal}+8 \mathrm{oz} / 100 \mathrm{gal})\end{array}$ & $49.0 \pm 27.5$ & $5.2 \pm 2.8$ & $7.8 \pm 3.0^{*}$ & $2.6 \pm 1.5$ & $14.2 \pm 12.7$ \\
\hline & & $\begin{array}{l}F=0.41 \\
\mathrm{df}=5,24 \\
P=0.83\end{array}$ & $\begin{array}{l}F=2.77 \\
\mathrm{df}=5,24 \\
P=0.04\end{array}$ & $\begin{array}{l}F=6.03 \\
\mathrm{df}=5,24 \\
P=0.001\end{array}$ & $\begin{array}{l}F=0.91 \\
\mathrm{df}=5,24 \\
P=0.49\end{array}$ & $\begin{array}{l}F=4.90 \\
\mathrm{df}=5,24 \\
P=0.003\end{array}$ \\
\hline
\end{tabular}

*Means within a column followed by an asterisk are significantly different from the control (Dunnett's test) at $P<0.05$.

population outbreaks are unknown. Most scales usually disperse as crawlers and then settle on a host plant, but $A$. kingii nymphs migrate twice, which may increase the chance of wind dispersal within an area. At high densities, more than one female may feed at the base of a petiole (Hamon et al. 1976) or along a branch, which increases the risk of branch dieback. However, exact damage thresholds have not been defined.

We were unable to achieve consistent, satisfactory control from the insecticide test using horticultural oil, acephate, bifenthrin, or imidacloprid, although the acephate and oil combination appeared the most promising of those treatments. Repeat applications may be needed, given the extended nymphal activity period. The systemic treatment of imidacloprid should have provided greater control of A. kingii if it feeds in the phloem (Salvatore 1997), but the exact placement of the stylet in the plant tissue is unclear. It is also possible that soil or trunk injections with imidacloprid could provide greater control, or that more time was needed for imidacloprid to reach its maximum efficacy (Sclar and Cranshaw 1996). Acephate may have been more effective because it is more soluble than imidacloprid, allowing more insecticide to move into nonvascular plant tissue (Rebek and Sadof 2003). Pyrethroid insecticides may not be viable scale control products because of their negative impacts on natural enemies and tendency to cause secondary pest outbreaks (Clarke et al. 1992).

\section{LITERATURE CITED}

Clarke, S.R., J.F. Negron, and G.L. Debarr. 1992. Effects of four pyrethroids on scale insect (Homoptera) populations and their natural enemies in loblolly and shortleaf pine seed orchards. J. Econ. Entomol. 85(4):1246-1252.

Hamon, A.B., P.L. Lambdin, and M. Kosztarab. 1976. Life history and morphology of Kermes kingii in Virginia (Homoptera: Coccoidea: Kermesidae). Virginia Polytech. Inst. \& State Univ. Res. Div. Bull. 111:1-31.

Harms, W.R. 1990. Live oak, pp. 751-754. In Burns, R.M., and B.H. Honkala (Eds.). Silvics of North America, Vol. 2. Agric. Handbook 654. USDA Forest Service, Washington DC.

Kosztarab, M. 1996. Scale Insects of Northeastern North America: Identification, Biology, and Distribution. Virginia Museum of Natural History, Martinsburg, VA. 650 pp.

Raven, J.A. 1983. Phytophages of xylem and phloem: A comparison of animal and plant sap-feeders. Adv. Ecol. Res. 13:135-234.

Rebek, E.J., and C.S. Sadof. 2003. Effects of pesticide applications on the euonymus scale (Homoptera: Diaspididae) and its parasitoid, Encarsia citrina (Hymenoptera: Aphelinidae). J. Econ. Entomol. 96(2):446-452.

Salvatore, M. 1997. General life history, pp. 251-256. In Ben-Dov, Y., and C.J. Hodgson (Eds.). Soft Scale Insects: Their Biology, Natural Enemies and Control, Vol. 7A. Elsevier, Amsterdam, The Netherlands. 
SAS Institute, Inc. 2001. JMP Start Statistics (2nd ed.). Duxbury, Pacific Grove, CA. 491 pp.

Scalenet. 2004. Scales on Fagaceae Quercus. www.sel.barc.usda.gov/scalenet/distrib.htm (accessed 5/26/05).

Sclar, D.C., and W.S. Cranshaw. 1996. Evaluation of new systemic insecticides for elm insect pest control. J. Environ. Hortic. 14(1):22-26.

Vranjic, J.A. 1997. Effects on host plant, pp. 323-336. In Ben-Dov, Y., and C.J. Hodgson (Eds.). Soft Scale Insects: Their Biology, Natural Enemies and Control, Vol. 7A. Elsevier, Amsterdam, The Netherlands.

Acknowledgments. We are grateful to St. Brendan Church, Cutter Cove Condominium, and the City of Clearwater Urban Forestry Division for their assistance with this project. We appreciate the taxonomic support provided by L. Buss (University of Florida), G.A. Evans, J.B. Heppner, J.R. King, and W.C. Welbourn (Division of Plant Industry, FL). Special thanks to P. Ruppert and Y. Wang (University of Florida) for helping with data collection and to M. Williams (Auburn University, AL) and G. Hodges (Division of Plant Industry, FL) for reviewing an earlier draft of this manuscript. This project was supported in part by a grant from the City of Clearwater Urban Forestry Division. This is the Florida Agricultural Experiment Station Journal Series No. R-10627.

\author{
${ }^{1}$ Graduate Research Assistant \\ 2*Assistant Professor \\ Entomology and Nematology Department \\ University of Florida \\ P.O. Box 110620 \\ Gainesville, FL 32611-0620, U.S.
}

*Corresponding author.
Résumé. La kermès du chêne rouge (Allokermes kingii Cockerell) est un insecte indigène retrouvé sur les chênes (Quercus spp.) des États-Unis. Son processus d'alimentation cause une mortalité progressive des branches, un dépérissement, une diminution de croissance et parfois la mortalité de l'arbre. Cet insecte produit une génération par année dans la plupart des régions des États-Unis, mais on a observé deux générations en Floride. Il a aussi infesté le Q. geminata et le Q. virginiana Miller, ce qui représente deux nouveaux hôtes sur la liste. Les insecticides testés (acephate, bifenthrin, imidacloprid, huile horticole, combinaison d'acephate et huile) sont apparus comme capable de supprimer les populations de nymphes, mais aucun n'a causé une mortalité supérieure à $42 \%$. Peu d'ennemis naturels ont été détectés lors de cette étude; ces derniers ont donc été considérés comme inefficaces pour diminuer sur le terrain les populations de kermès.

Zusammenfassung. Allokermes kingii (Cockerell) ist ein einheimisches, gall-ähnliches Schadinsekt, welches in den USA an Eichen gefunden werden kann. Seine Fraßgewohnheiten führen zu Astabsterben, reduzierten Wachstumsraten und gelegentlich zu Baumsterben. Allokermes kingii (Cockerell) hat in den meisten Teilen der USA eine Generation pro Jahr, aber in Florida fanden wir zwei Generationen. Es befällt auch Quercus geminata Small und Q. virginiana Miller, die neue Wirtspflanzen repräsentieren. Die getesteten Insektizide schienen die Nymphen-Population zu unterdrücken, aber keine erreichte mehr als eine 42 \%ige Sterberate. Auf den untersuchten Bäumen wurden sehr wenig natürliche Feinde gefunden, so dass diese nicht in die Reduktion der Insektenpopulation eingerechnet wurden.

Resumen. La escama kermes del encino rojo norteño, Allokermes kingii (Cockerell), es un insecto nativo parecido a la agalla encontrado en encinos (Quercus spp.) en los Estados Unidos. Su alimentación causa muerte descendente de las ramas, efecto de bandera, tasas reducidas de crecimiento y muerte ocasional de árboles. Allokermes kingii tiene una generación por año a través de los E.U., pero se encontraron dos generaciones en un año en Florida. También infesta Q. geminata Small y Q. virginiana Miller, los cuales representan nuevos registros de hospederos. Los insecticidas probados (acefato, bifendrín, imidacloprid, aceite hortícola, y la combinación de acefato y aceite) parecen suprimir la población de ninfas, pero no causaron mortalidad $>42 \%$. Hubo muy pocos enemigos naturales en los árboles estudiados y resultaron poco efectivos para reducir la población de escamas. 